\title{
THE CAUSALITY BETWEEN INFLATION AND UNEMPLOYMENT: THE INDONESIAN EVIDENCE
}

\author{
Gatot SASONGKO ${ }^{1}$, Andrian Dolfriandra HURUTA ${ }^{2}$ \\ Universitas Kristen Satya Wacana, Salatiga, Indonesia \\ E-mails: ${ }^{1}$ gatot.sasongko@staff.uksw.edu (corresponding author); ${ }^{2}$ andrian.huruta@staff.uksw.edu \\ Received 21 June 2018; accepted 05 September 2018

\begin{abstract}
Two closely watched indicators of economic performance are inflation and unemployment. This study empirically analyzes the causality between inflation and unemployment in Indonesia during 1984 to 2017. The data were gathered from the Indonesian Central Bureau of Statistics. Methodologically, this study employed the Granger Causality test and Vector Autoregression to determine the causality between inflation and unemployment. The results show that there is a one-way causality between inflation and unemployment. The findings imply that unemployment causes inflation, but not vice versa. Next inflation and unemployment are also closely related to other determining factors, such as season, household income, and the decisions to attend school or to perform the housekeeping.
\end{abstract}

Keywords: granger causality, inflation, unemployment, vector autoregression.

JEL Classification: E600, E610.

\section{Introduction}

Post global financial crises (2008) have forced countries to adopt expansionary and stimulating macroeconomic policies aiming to reduce unemployment. Some countries, such as United Kingdom, Germany, and the United States of America have become successful in lowering the unemployment in their labor markets. However, Spain and Italy are stuck at high rates of unemployment with rigid labor markets (Bhattarai 2016). The unemployment could be stabilized towards their natural rates by stimulating the aggregate demand through fiscal or monetary policies with or without some increase in price levels (Keynes 1936, Phllips 1958, Benati 2015, Blanchard 2016).

Short-term economic problems, such as inflation and unemployment are among the most notable macroeconomic problems all the time (Al-zeaud 2014, Arshad 2014, Bhattarai 2016, Caporale and Škare 2011, Cioran 2014, Furuoka 2007, Furuoka 2008, Israel 2015, Katria et al., 2011, Kogid et al. 2011, Mahmood et al. 2013, Okafor et al.
2016, Sảidu and Muhammad 2015, Ştefan and Bratu 2016, Thayaparan 2014, Touny 2013, Umaru and Zubairu 2012, Zaman et al. 2011, Pallis 2006, Benati 2015, Blanchard 2016). The Indonesian government started to focus on inflation when Indonesia experienced an economic shock during the transition period (1965-1969). Fortunately, the Indonesian government managed to control the inflation rate as Indonesia only had an inflation rate of below $10 \%$ in 1969 (Bank Indonesia 2004). However, the monetary crisis hit Indonesia again in 1997-1998 that resulted in the inflation rate of $58.4 \%$. During the post-monetary crisis period, Indonesia managed to recover that caused the inflation rate to be below two digits. Further, the global financial crisis hit the global economy in 2008, but the Indonesian inflation rate remained stable. One of the likely factors of this condition is the government' various economic rescue programs such as the tight money or contractive policy that was effective in taming the inflation rate. Besides, the Inflation Targeting Framework that was implemented by Bank Indonesia (the Indonesian central bank) since July

Copyright $\odot 2019$ The Authors. Published by VGTU Press.

This is an Open Access article distributed under the terms of the Creative Commons Attribution License (http://creativecommons.org/licenses/by/4.0/), which permits unrestricted use, distribution, and reproduction in any medium, provided the original author and source are credited.. 
2005 (Bank Indonesia 2017) and the empowerment of the Regional Inflation Monitoring Team in each local region facilitated further the inflation control (Sasongko and Huruta 2018).

The high inflation rate in 1965 also caused a high unemployment rate (read: stagflation). Since 1965, the unemployment rate has increased by $5-6 \%$ per year. However, similar to the inflation rate, the Indonesian government managed to reduce the unemployment rate to less than $10 \%$ (Bank Indonesia 2004). Every government closely monitor inflation and unemployment as the two main economic performance indicators. Statisticians combine inflation and unemployment data to develop the misery index that aims to measure the health of an economy. One of the economic principles is the short-term trade-off between inflation and unemployment. If fiscal and monetary policymakers increase aggregate demands and economy along the short-run aggregate demand curve, they can reduce unemployment temporarily, albeit with an increase in inflation rate. On the other hand, if monetary and fiscal policymakers reduce aggregate demands and economy along the short-run aggregate demand curve, they can curb inflation but also increase unemployment temporarily (Mankiw et al. 2013).

This study aims to investigate the trade-off between inflation and unemployment as found by Phllips (1958) especially on the causality between inflation and unemployment in Indonesia during 1984 to 2017. It is clear the importance to recognize the relationship between inflation and unemployment when determining the macroeconomic policies for an economy. Despite the availability of several studies that examined the Phillips curve hypothesis, there is still a shortage of applied studies that investigate this hypothesis under developing countries where the majority of research has concentrated on the developed nations. The outcomes of this study may help policymakers to formulate better policies that can achieve their objectives of price stability and full employment in Indonesia.

\section{Literature review}

Several studies have investigated the relationship between inflation and unemployment. Al-zeaud (2014) does not find a causal relationship between inflation and unemployment in Jordan because the study does not include foreign labor when measuring the unemployment level, thus inhibiting the trade-offs between these two variables in the short term. Further, Furuoka (2008) also does not find the causality between inflation and unemployment in the Philippines. The socioeconomic factors such as the output gaps likely explain the Phillips curve better in the Philippine context. In Nigeria, Umaru and Zubairu (2012) indicate that there is no causality between inflation and unemployment. The findings suggest that the Phillip curve does not apply in
Nigeria and it is necessary to use the unemployment or inflation theory that is based more on the Nigerian data and situation.

Besides studies that show no causal relationship between inflation and unemployment, Caporale and Škare (2011) demonstrate that there is a one-way causal relationship between inflation and job opportunities. Their findings, based on the study on the Organisation for Economic Cooperation and Development (OECD) countries, thus suggest that inflation affects job opportunities, but not the way around. This condition recommends policymakers to pay more attention to the short-term and long-term job and output growth. In Malaysia, Furuoka (2007) also finds the one-way causality between inflation and unemployment, implying that inflation leads to unemployment but not the way around. The study also demonstrates the cointegration and causal relationship between inflation and unemployment in Malaysia. In other words, the results confirm the existence of the Phillips curve. Still in the same country, Kogid et al. (2011) document the one-way causality between inflation and unemployment. Their findings imply that inflation causes unemployment, but not vice versa. The results also confirm the trade-off relationship between inflation and unemployment in Malaysia and the government needs to ensure that the economic policies will facilitate sustainable economic growth in the future. Using the US data, Ştefan and Bratu (2016) also find the one-way relationship between inflation and unemployment, suggesting that inflation explains unemployment but not vice versa. Their findings suggest that policymakers should develop programs that reduce unemployment such as productive labor projects while at the same time also control inflation. Besides, the programs should focus on replacing foreign labors with local labors and on ensuring that the aggregate demands reach the optimal unemployment and inflation levels that will eventually support the long-term economic growth. The Pakistani study of Mahmood et al. (2013) demonstrate the one-way causality between inflation and unemployment, implying that inflation affects unemployment but not the way around. The study also suggests that the Pakistani policymakers maintain the equilibrium point between inflation, unemployment, and interest rate to control for economic shocks. Lack of focus on one of the three variables likely affects the economy. Still using the Pakistani data, Zaman et al. (2011) find the long-term relationship and one-way causality between inflation and unemployment, denoting that inflation causes unemployment but not vice versa. The results also indicate that increasing inflation likely increases employment opportunities that eventually facilitates growth. The study empirically confirms the existence of the Phillips curve in Pakistan, both in the shortterm and in the long-term. Nigeria also exhibits the one-way causality between inflation and unemployment by Sa'idu 
and Muhammad (2015) that indicating inflation leads to unemployment but not the other way around. Their results recommend the joint efforts of all policymakers to restructure the economy to manage price instability and improve the infrastructures.

Further, Katria et al. (2011) who analyze the South Asian Association for Regional Cooperation (SAARC) countries, find a negative relationship between inflation and unemployment. Their results indicate that the collaboration between monetary and fiscal policies manages to stabilize the business cycle. Next, the Nigerian study by Okafor et al. (2016) indicates that inflation negatively affects unemployment. Their results recommend that policymakers not only rely on monetary targets but also on output targets through the economy deepening to maintain the optimal inflation rate and the minimal unemployment level. In a similar vein, Cioran (2014) demonstrates that inflation negatively affects unemployment in Romania and the European Union (EU). The findings suggest that inflation rate is an effective instrument to prevent increasing unemployment in the EU and Romania.

Besides the negative results, other studies find the positive relationship. For example, using the Egyptian data, Touny (2013) documents that unemployment positively affects inflation in the long run. The results recommend that policymakers implement their monetary policies to overcome the inflationary pressure regardless of the negative effects of unemployment. Further, Israel (2015) who analyzes several developed countries such as France, Germany, the UK, and the US, show the long-term positive relationship between inflation and unemployment. This positive relationship is closely related to the political intervention. The condition causes two problems, namely: (1) monetary expansion on the income and wealth distribution leads to the increasing gap between the poor and the rich. The increasing gap causes the labor market to be less flexible and increases unemployment, (2) monetary expansion causes less fluctuation but eventually increases unemployment. Using the Uni European Countries data, Pallis (2006) investigated the relationship between inflation and unemployment in the 10 new European Union countries find that in almost all countries the interaction between the price inflation rate and the unemployment level took place in a rather long time period, reaching in some cases the lag of year four. In Pakistan, Ul-Haq et al. (2012) provided further support for the existence of a long-term relationship between unemployment and inflation. On the other hand, the outcomes of VECM revealed a positive and significant correlation between inflation and unemployment either in the long term or the short term.

Other studies demonstrate the two-way causality between inflation and unemployment. For example, Arshad (2014) shows the two-way causality between inflation rate and unemployment in Pakistan, implying that inflation causes unemployment, and unemployment causes inflation. The data suggest that inflation rate explains the variance of unemployment better than economic growth while unemployment contributes to the variance of inflation more than economic growth. In Sri Lanka, Thayaparan (2014) finds the two-way causality between inflation and unemployment, implying that inflation causes unemployment and unemployment causes inflation. The findings indicate that both unemployment and inflation significantly affect the Sri Lankan macroeconomic conditions. Next Bhattarai (2016) finds bidirectional causality as well as cointegrating relationships between unemployment and inflation among the OECD countries. Estimates of a vector autoregression (VAR) model on these trade-offs also support such hypothesis.

Overall, these studies show varying results such as one-way causality, two-way causality, and no causal relationship between inflation and unemployment. Further, these studies also use different analytical models, such as Granger Causality, Johansen Cointegration, Autoregressive Distributive Lag, Error Correction Model, Vector Error Correction Model, Panel Data, Vector Autoregression, and etc. It can be concluded from the previous discussion that there is an uncertain relationship between inflation and unemployment of different economies in the certain period.

\section{Research methods}

This study uses the secondary data from the central bureau of statistics and the world bank publication. More specifically, the study relied on the time-series data from 1984 to 2017. Further Granger Causality and Vector Autoregression used to analyze the data. Before running the Granger Causality and Vector Autoregression model, this study initially ran the stationary and the lag length test. The following are the models for the stationary test and the test statistic (Brooks 2008).

$$
\begin{gathered}
\Delta Y t=\varphi Y t-1+\varphi t ; \\
\text { Test statistic }=\frac{\varphi}{S . E \varphi} .
\end{gathered}
$$

After running the stationary test, this study ran the lag length test. There are various approaches to select the optimal lag length, such as Likelihood Ratio, Final Prediction Error, Akaike Information Criterion and Schwarz Information Criterion (Rosadi 2012). This study uses the Akaike Information Criterion (AIC). The minimum value of the AIC suggests the optimal lag (Ivanov and Kilian 2005). After completing the lag length test, this study ran the Granger Causality test (Rosadi 2012):

$$
X t=\sum_{i=1}^{m} a_{i} X t-1+\sum_{j=1}^{n} b_{j} Y t-1+\mu t
$$




$$
Y t=\sum_{i=1}^{r} c_{i} X t-1+\sum_{J=1}^{s} d_{j} Y t-1+V t .
$$

The above equation indicates that $X_{t}$ is inflation, and $Y_{t}$ is unemployment, while $\mu \mathrm{t}$ and $V t$ are error terms that are assumed to contain no serial correlation and $m=n=$ $r=s$. The Granger Causality test produces four possible results as represented by the following equations:

1. If $\Sigma a j \neq 0$ and $\Sigma b j=0$, then there is a one-way causality from inflation to unemployment.

2. If $\Sigma a j=0$ and $\Sigma b j \neq 0$, then there is a one-way causality from unemployment to inflation.

3. If $\Sigma a j=0$ and $\Sigma b j=0$, then there is no causal relationship between inflation and unemployment.

4. If $\Sigma a j \neq 0$ and $\Sigma b j \neq 0$, then there is a two-way causality between inflation and unemployment.

Further, this study ran the Vector Autoregression after completing the Granger Causality test. The Vector Autoregression (VAR) is commonly used for forecasting systems of interrelated time series and for analyzing the dynamic impact of random disturbances on the system of variables. The reduced form VAR approach sidesteps the need for structural modeling by treating every endogenous variable in the system as a function of $p$-lagged values of all of the endogenous variables in the system. The following is the equation in the Vector Autoregression $(p)$ with $k$-endogen variable $y_{t}=\left(y_{1 t}, y_{2 t}\right.$, $\ldots, y_{k t}$ ) (Lütkepohl 2006).

$$
y_{t}=A_{1} y_{t-1}+\ldots+A_{p} y_{t-p}+C x_{t}+\epsilon_{t}
$$

where:

$y_{t}=\left(y_{1 t}, y_{2 t}, \ldots, y_{k t}\right)^{\prime}$ is a $k \times 1$ vector of endogenous variables;

$x_{t}=\left(x_{1 t}, x_{2 t}, \ldots, x_{d t}\right)^{\prime}$ is a $d \times 1$ vector of exogenous variables;

$A_{1}, \ldots, A_{p}$ are $k \times k$ matrices of lag coefficients to be estimated;

$C$ is a $d \times k$ matrix of exogenous variable coefficients to be estimated;

Table 2. Lag length test

\begin{tabular}{|c|c|c|c|c|c|c|}
\hline Lag & LogL & LR & FPE & AIC & SC & HQ \\
\hline 0 & -151.4651 & NA & 197.5714 & 10.96179 & 11.05695 & 10.99088 \\
\hline 1 & -150.5083 & 1.708562 & 245.9338 & 11.17917 & 11.46464 & 11.26644 \\
\hline 2 & -145.1985 & 8.723246 & 225.3365 & 11.08561 & 11.56140 & 11.23106 \\
\hline 3 & -125.0476 & $30.22635^{\star}$ & $72.08667^{\star}$ & $9.931972^{\star}$ & $10.59807^{*}$ & $10.13561^{\star}$ \\
\hline 4 & -121.2335 & 5.176270 & 74.94396 & 9.945251 & 10.80167 & 10.20707 \\
\hline 5 & -120.3520 & 1.070367 & 97.66239 & 10.16800 & 11.21473 & 10.48800 \\
\hline
\end{tabular}

${ }^{*}$ indicates the optimal lag. $\epsilon_{t}=\left(\epsilon_{1 t}, \in_{2 t}, \ldots, \in_{k t}\right)^{\prime}$ is a $k \times 1$ white noise innovation process, with $\mathrm{E}\left(\in_{t}\right)=0, \mathrm{E}\left(\in_{t} \in_{t}^{\prime}\right)=\sum \in$, and $\mathrm{E}\left(\epsilon_{t}\right.$ $\left.\in_{s}^{\prime}\right)=0$ for $t \neq s$.

\section{Results}

Table 1 below shows the results of the stationarity test using the Augmented Dickey-Fuller (ADF) method.

Table 1 indicates that inflation is stationary at the order of integration of level or I(0) while the unemployment level

Table 1. Stationarity test

\begin{tabular}{|l|c|c|}
\hline \multicolumn{1}{|c|}{ Variable } & $p$-value & Conclusion \\
\hline Inflation & $0.0000^{*}$ & $\mathrm{I}(0)$ \\
\hline Unemployment & 0.3012 & the series is not stationary \\
\hline DUnemployment $^{* *}$ & $0.0000^{*}$ & $\mathrm{I}(1)$ \\
\hline
\end{tabular}

${ }^{*}$ indicates the rejection of the null hypothesis at $5 \%$ of significance level.

** DUnemployment implies that Unemployment at the first difference $[\mathrm{I}(1)]$.

is not stationary at the order of integration of level, prompting us to have the first difference technique. The order 1 or I(1) differencing shows that DUnemployment does not contain the unit root anymore because it is now stationary. Further, determine the optimal length of lag by using Lag Length Test as can be seen in Table 2.

Table 2 suggests the optimal lag to indicate the dependence of a variable on its lagged value and other endogenous variables is lag 3 , implying that we have to use lag 3 to investigate the causality between inflation and DUnemployment. This decision is indicated by the Akaike Information Criterion (AIC) value of 9.931972 that is smaller than the AIC values at the other lags. After ran the lag length test, this study ran the Granger Causality test using lag 3. The results of Granger Causality test can be seen in Table 3 .

Table 3 reveals that the null hypothesis proposing that DUnemployment does not Granger Cause inflation is rejected, implying that DUnemployment exhibits the Granger Cause on inflation. The results suggest that DUnemployment granger cause inflation, but not vice 
Table 3. Granger causality test

\begin{tabular}{|l|c|c|c|}
\hline Pairwise Granger Causality Tests \\
\hline Sample: 19842017 & Obs & F-Statistic & Prob. \\
\hline Lags: 3 & 30 & 0.72869 & 0.5454 \\
\hline Null Hypothesis: & & 33.0657 & $2 . E-08$ \\
\hline Inflation does not Granger Cause DUnemployment & & \\
\hline Dunemployment does not Granger Cause Inflation &
\end{tabular}

versa. The decision of rejecting the null hypothesis is based on the probability value of 2 .E- 08 that is lower than $\alpha=5 \%$. After ran the Granger Causality, this study ran the Vector Autoregression. Variables in a Vector Autoregression model are determined simultaneously and rely more on historic patterns of data to establish relations between unemployment and inflation than economic theories (Bhattarai 2016). The results of Vector Autoregression can be seen in Table 4 .

Table 4 indicates that a simple Vector Autoregression model with three lags on inflation and DUnemployment shows that Inflation is significantly influenced by DUnemployment(-2), DUnemployment(-3) and inflation(-1). It implies that the influence of DUnemployment(-2), DUnemployment $(-3)$ and inflation( $(-1)$ have a large contribution to the movement of inflation in Indonesia. Estimates of Vector Autoregression also support by the Impulse Response Functions (IRFs). The results of the Impulse Response Functions (IRFs) can be seen in Figure 1.

Impulse Response Functions (IRFs) was calculated for DUnemployment and inflation to address the reaction of the economy to external changes (shocks). The results of the IRFs analysis show that there is a trade-off between inflation and DUnemployment as shown by the IRFs of
DUnemployment to inflation. Overall, estimate results of Granger Causality, Vector Autoregression, and Impulse Response Functions (IRFs) prove that the DUnemployment is more instrumental to explain inflation in Indonesia.

Further, this result is supported by Touny (2013) who finds the positive effect of unemployment on inflation. The normalized cointegration equation reveals that unemployment gap has a long-run positive effect on the changes in the inflation rate, which is consistent with "Lucas Critique" where a policy of inflation would fail to reduce the unemployment rate in the long run, because workers would eventually adjust their expectations of inflation. Further, the more rapid the reduction in the unemployment rate, the less disinflation is achieved at each unemployment rate level. Even at the cases where the unemployment rate is very high, the inflation rate falls little and thus the economy is moving too rapidly out of the recession (Pallis 2006). Other findings by Ul-Haq et al. (2012) also suggest that policy makers should pay special attention to this relationship between inflation and unemployment when they are going to design macroeconomic policies.

Thus, when inflation does not support DUnemployment, it is necessary to analyze factors that affect DUnemployment. Table 5 below presents the information on the number of

Table 4. VAR Model of inflation and DUnemployment for Indonesia (1984-2017)

\begin{tabular}{|l|c|c|c|c|}
\hline \multirow{2}{*}{} & \multicolumn{2}{|c|}{ DUnemployment } & \multicolumn{2}{c|}{ Inflation } \\
\cline { 2 - 5 } & Coefficients & t-prob & Coefficients & t-prob \\
\hline DUnemployment(-1) & -0.135523 & 0.20747 & 0.709939 & 1.30180 \\
\hline DUnemployment(-2) & -0.181229 & 0.20753 & -6.937364 & 1.30223 \\
\hline DUnemployment(-3) & 0.217161 & 0.24175 & 11.60203 & 0.51692 \\
\hline Inflation(-1) & 0.024945 & 0.01742 & 0.421936 & 0.09564 \\
\hline Inflation(-2) & 0.003714 & 0.01524 & 0.042180 & 0.09495 \\
\hline Inflation(-3) & -0.006079 & 0.01513 & 0.021545 & 2.14168 \\
\hline Constant & -0.186910 & 0.34132 & 4.400302 & \\
\hline & & & & 0.813392 \\
\hline $\mathrm{R}^{2}$ & 0.124570 & & 16.70883 & \\
\hline F-statistic & 0.545466 & & -94.43436 & \\
\hline Log-likehood & -39.33832 & & 6.762290 & \\
\hline AIC & 3.089221 & & 7.089236 & \\
\hline Swarz SC & 3.416167 & & & \\
\hline
\end{tabular}


the population 15 years of age or over who worked by the main employment status.

Table 5 indicates the sharp increase in the number of the working-age population with the employee status, both in absolute and relative terms. The number of employees in 2001 was $26,579,000$ or $29.7 \%$ of the total working age population. The number increased to $47,420,633$ or $38.08 \%$ of the total working age population in 2017. Increased investment mainly drives the increasing number of employees. Djambaska and Lozanoska (2015), Yelwa et al. (2015), Touny (2013), Israel (2015), Ul-Haq et al. (2012), Bhattarai (2016), and Pallis (2006) support the results by arguing that

Response to Cholesky One S.D. Innovations \pm 2 S.E.

\section{Response of DUNEMPLOYMENT to DUNEMPLOYMENT}

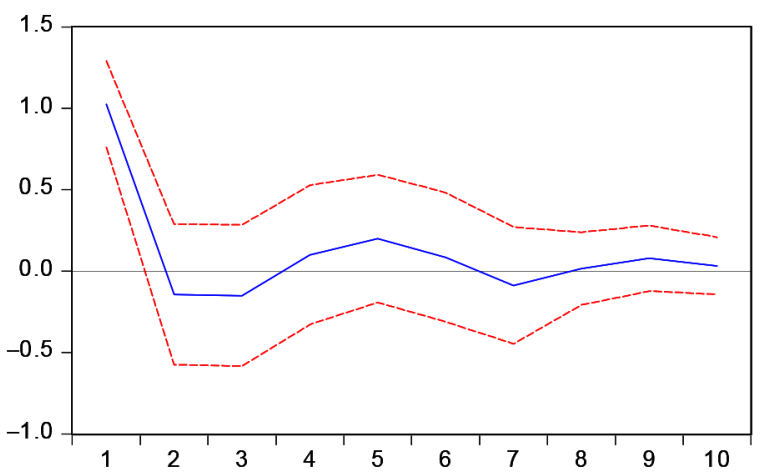

Response of INFLATION to DUNEMPLOYMENT

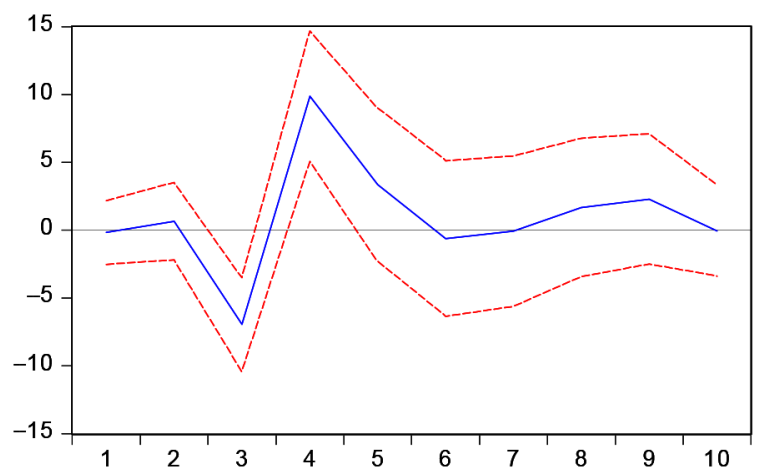

Response of DUNEMPLOYMENT to INFLATION

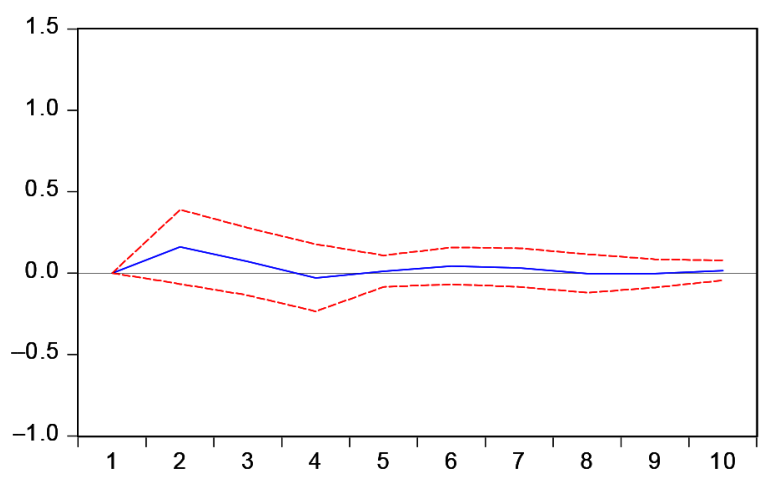

Response of INFLATION to INFLATION

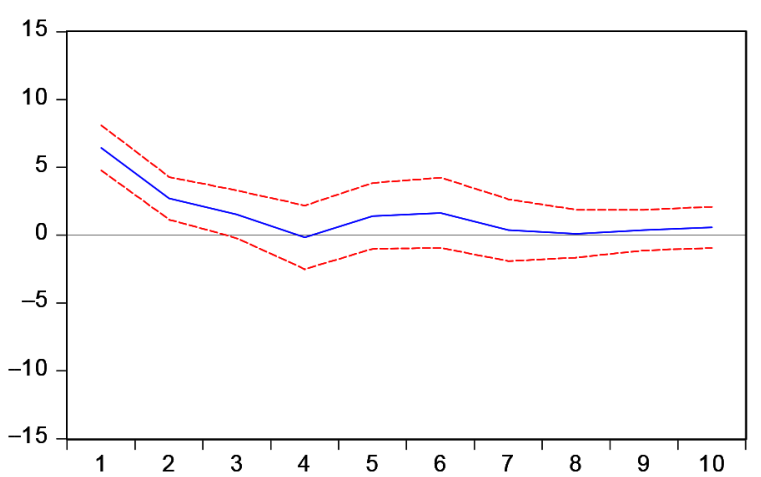

Figure 1. Impulse responses to DUnemployment and inflation shocks

Table 5. The Population 15 Years of age or over by the main employment status (2001-2017) (source: Badan Pusat Statistik (2017a), processed))

\begin{tabular}{|c|l|c|c|c|c|}
\hline \multirow{2}{*}{ Number } & \multicolumn{1}{|c|}{ Main Employment Status } & \multicolumn{2}{c|}{2001} & \multicolumn{2}{c|}{2017} \\
\cline { 3 - 6 } & & Amount & $\%$ & \multicolumn{2}{c|}{ Amount } \\
\hline 1 & Self-employed & $17,451,704$ & 19.22 & $21,849,573$ & 17.54 \\
\hline 2 & Employer Assisted by Temporary/ Unpaid Worker & $20,329,073$ & 22.39 & $21,275,899$ & 17.08 \\
\hline 3 & Employer Assisted by Permanent/ Paid Worker & $2,788,878$ & 3.07 & $4,446,024$ & 3.57 \\
\hline 4 & Employee & $26,579,000$ & 29.27 & $47,420,633$ & 38.08 \\
\hline 5 & Casual Agricultural Worker & $3,633,126$ & 4.00 & $5,360,306$ & 4.30 \\
\hline 6 & Casual Non-Agricultural Worker & $2,439,035$ & 2.69 & $6,021,760$ & 4.84 \\
\hline 7 & Family/ Unpaid Worker & $17,586,601$ & 19.37 & $18,164,654$ & 14.59 \\
\hline 8 & No Answer & - & - & - & - \\
\hline & Total & $90,807,417$ & 100.00 & $124,538,849$ & 100.00 \\
\hline
\end{tabular}


investment is a determining factor in reducing unemployment.

Further, another factor that affects the number of unemployment is the industry in which the population work. Table 6 below shows the data on the population 15 years of age or over who worked by industry.

The proportion of the population above 15 years who worked at the primary sectors (agriculture, plantation, forestry, hunting, and fishery) declined sharply. In 1991, $53.29 \%$ of the working population worked in the primary sectors, and proportion declined to $31.74 \%$ in 2016 . The agricultural sector dominates the primary sectors because of most population work in this sector (Thayaparan 2014, Yelwa et al. 2015, Kebschull 1987, Israel 2015). Edelman (2013) confirms the findings by suggesting that farmers in Latin America and Indonesia live in communities with exclusive land rights and most of them use the lands for agricultural activities. The agricultural works in Indonesia are heavily affected by the season factor, especially before 2005 because of the less developed irrigation system. More specifically, the agricultural sector greatly depends on the sufficient availability of rainfall. Farmers begin to cultivate their soils after rain falls. Rain usually starts to fall in
October and the dry season starts in April. The following Table 6 displays the open unemployment level based on the February and August surveys. February is in the rainy season while August is in the dry season. The open unemployment rate was higher in August, a month in the dry season than in February, a rainy month. The average August unemployment rate was 8,599,944 while in February the average unemployment level was $8,599,676$. The proportion of the population working in the agricultural sector was so high that the season factor significantly affected the unemployment rate. However, the annual difference of the unemployment level between these two months tended to decline. There was even no difference of the open unemployment level between February and August in 2017 (Badan Pusat Statistik 2017d). Further estimates of an Independent Sample T Test also support the data. Estimate results can be seen in Table 7 .

The significance value ( 2 tailed) of 1.000 is bigger than the tolerance value of $5 \%(0.05)$ implies that there is no difference between February and August unemployment rate. The more developed irrigation system reduce the farmers' dependence on rainfall and eventually on the season. Next, the Indonesian working-age population who attended

Table 6. Population 15 years of age or over who worked by main industry (1991-2016) (source: Badan Pusat Statistik (2017b), processed))

\begin{tabular}{|c|l|c|c|c|c|}
\hline \multirow{2}{*}{ Number } & \multirow{2}{*}{ Main Industry } & \multicolumn{2}{|c|}{1991} & \multicolumn{2}{c|}{2016} \\
\cline { 3 - 6 } & & Amount & $\%$ & Amount & $\%$ \\
\hline 1 & Agriculture, Plantation, Forestry, Hunting, and Fisheries & $39,385,946$ & 53.29 & $38,291,111$ & 31.74 \\
\hline 2 & Mining and Quarrying & 551,581 & 0.75 & $1,311,834$ & 1.09 \\
\hline 3 & Manufacturing Industry & $7,712,468$ & 1.43 & $15,975,086$ & 1.24 \\
\hline 4 & Electricity, Gas, and Water & 148,480 & 0.20 & 403,824 & 0.33 \\
\hline 5 & Construction & $2,415,002$ & 3.27 & $7,707,297$ & 6.39 \\
\hline 6 & Trade, Restaurants, and Accomodation Services & $11,190,391$ & 1.14 & $28,495,436$ & 23.62 \\
\hline 7 & Transportation, Warehousing, and Communication & $2,475,803$ & 3.35 & $5,192,491$ & 4.30 \\
\hline 8 & Financial, Real Estate, and Business Services & 515,401 & 0.70 & $3,481,598$ & 2.89 \\
\hline 9 & Community, Social, and Personal Services & $9,377,036$ & 12.69 & $19,789,020$ & 1.40 \\
\hline 10 & Undefined & 139,516 & 0.19 & - & - \\
\hline
\end{tabular}

Table 7. Independent Sample T Test for Unemployment on February and August (1986-2017)

\begin{tabular}{|c|c|c|c|c|c|c|c|c|c|c|}
\hline & & \multicolumn{2}{|c|}{$\begin{array}{c}\text { Levene's Test } \\
\text { for Equality of } \\
\text { Variances }\end{array}$} & \multicolumn{7}{|c|}{ t-test for Equality of Means } \\
\hline & & \multirow[t]{2}{*}{$\mathrm{F}$} & \multirow[t]{2}{*}{ Sig. } & \multirow[t]{2}{*}{$\mathrm{t}$} & \multirow[t]{2}{*}{ Df } & \multirow{2}{*}{$\begin{array}{c}\text { Sig. } \\
\text { (2-tailed) }\end{array}$} & \multirow{2}{*}{$\begin{array}{c}\text { Mean } \\
\text { Difference }\end{array}$} & \multirow{2}{*}{$\begin{array}{l}\text { Std. Error } \\
\text { Difference }\end{array}$} & \multicolumn{2}{|c|}{$\begin{array}{c}\text { 95\% Confidence Interval of } \\
\text { the Difference }\end{array}$} \\
\hline & & & & & & & & & Lower & Upper \\
\hline \multirow{2}{*}{ Unmpl } & $\begin{array}{l}\text { Equal variances } \\
\text { assumed }\end{array}$ & .002 & .967 & .000 & 24 & 1.000 & -268.00000 & $6.06551 \mathrm{E} 5$ & $-1.25213 \mathrm{E} 6$ & $1.25159 \mathrm{E} 6$ \\
\hline & $\begin{array}{l}\text { Equal variances } \\
\text { not assumed }\end{array}$ & & & .000 & 23.945 & 1.000 & -268.00000 & $6.06551 \mathrm{E} 5$ & $-1.25228 \mathrm{E} 6$ & $1.25174 \mathrm{E} 6$ \\
\hline
\end{tabular}


Table 8. Independent Sample T Test for Working Age Between Attend School and Housekeeping (1986-2017)

\begin{tabular}{|c|c|c|c|c|c|c|c|c|c|c|}
\hline & \multicolumn{2}{|c|}{$\begin{array}{l}\text { Levene's Test } \\
\text { for Equality of } \\
\text { Variances }\end{array}$} & \multicolumn{7}{|c|}{ t-test for Equality of Means } \\
\hline & & \multirow[t]{2}{*}{$\mathrm{F}$} & \multirow[t]{2}{*}{ Sig. } & \multirow[t]{2}{*}{$\mathrm{T}$} & \multirow[t]{2}{*}{ df } & \multirow{2}{*}{$\begin{array}{c}\text { Sig. } \\
\text { (2-tailed) }\end{array}$} & \multirow{2}{*}{$\begin{array}{c}\text { Mean } \\
\text { Difference }\end{array}$} & \multirow{2}{*}{$\begin{array}{l}\text { Std. Error } \\
\text { Difference }\end{array}$} & \multicolumn{2}{|c|}{$\begin{array}{l}\text { 95\% Confidence Interval of } \\
\text { the Difference }\end{array}$} \\
\hline & & & & & & & & & Lower & Upper \\
\hline \multirow[b]{2}{*}{ WorkAge } & $\begin{array}{l}\text { Equal varian- } \\
\text { ces assumed }\end{array}$ & 4.160 & .046 & -48.096 & 60 & .000 & -9.88226 & .20547 & -10.29326 & -9.47126 \\
\hline & $\begin{array}{l}\text { Equal va- } \\
\text { riances not } \\
\text { assumed }\end{array}$ & & & -48.096 & 51.170 & .000 & -9.88226 & .20547 & -10.29472 & -9.46980 \\
\hline
\end{tabular}

school or performed the housekeeping increased. The number of economically inactive women due to housekeeping increased both in absolute and relative terms (Ehrenberg and Smith 2012). In 2005, the number of the working age population who performed the housekeeping (mostly women) was $17,275,478$ or $17.08 \%$ of the total labor force. The number increased to $36,078,772$ or $18.78 \%$ of the labor force in 2017 (Badan Pusat Statistik 2017c). The estimates of an Independent Sample T Test also support the data. Estimate results can be seen in Table 8 .

The significance value ( 2 tailed) of 0.000 is lower than the tolerance value of $5 \%$ ( 0.05$)$ implies that there is a difference between the Indonesian working-age population who attended school and performed the housekeeping. Ehrenberg and Smith (2012) confirm the data by arguing that women spend a significant portion of their time to housekeeping such as cooking or taking care of their children. Women prefer housekeeping to enter the labor market because housekeeping is also a productive activity.

Further, the number of the population 15 years of age or over who attended school increased from $9,147,830$ in 2005 to $15,244,852$ in 2017. However, the proportion of the working-age population who attended school decreased from $9.04 \%$ in 2005 to $7.94 \%$ in 2017 . Higher school attendance decreases the number of unemployment. Hubacek et al. (2007) support the findings by demonstrating that the economic success of the developing Asian countries enhances the quality of life of their population. Most Asian population experience the transition from poverty to sufficient fulfillment of food and clothes. Further, they aspire to not only meet their basic needs of food and clothes, but also to enjoy a higher quality of life from highly nutritious food, life comfort, medical treatments, and other highly qualified services.

\section{Conclusions}

This study suggests the one-way relationship between inflation and DUnemployment. More specifically, the Granger Causality, Vector Autoregression, and Impulse Response
Functions (IRFs) model show that from 1984 to 2017, DUnemployment causes inflation, but not vice versa. The results imply that the Phillips model (Phllips 1958) that proposes the reciprocal relationship between inflation and unemployment is not empirically supported in Indonesia. These findings also different with the most recently by Blanchard (2016) who find that The US Phillips curve is alive and well (or at least as well as it has been in the past).

Various factors affect the Indonesian unemployment rate, such as: (1) The season factor significantly affects unemployment, albeit with the declining magnitude, because the agricultural sector still absorbs a significant portion of the Indonesian labor force; (2) Increased income encourages young labor force (15-19 years) to delay entering the labor market but to continue their studies; and (3) Better economic condition also increases the number of non-labor force. More specifically, women prefer becoming housewives (caring for their households) in entering the labor market because caring for households is also a productive activity (Ehrenberg and Smith 2012).

Inflation is a less effective policy instrument to overcome the unemployment problem in Indonesia. This argument implies that increasing the inflation rate is ineffective to reduce the unemployment rate. Numerous facts indicate that other variables affect the Indonesian unemployment rate. However, it is viable to increase the unemployment rate to control inflation, although this policy has to be implemented carefully. Further, the Indonesian geographical condition that consists of thousands of islands likely causes the implementation of macro policies to take a longer time because of the greater needs to adjust for the inter-region differences. Thus, the use of the panel data model likely accounts for the possible inter-region variances better.

\section{References}

Al-zeaud H (2014) The trade-off between unemployment and inflation evidence from causality test for Jordan. International Journal of Humanities and Social Science 4 (4): 103-111. 
Arshad I (2014) Examining relationship between macroeconomic variables using Var Approach. In: Proceedings of the 2014 International Conference on Industrial Engineering and Operations Management. Bali, 2393-2401 http://ieomsociety. org/ieom2014/pdfs/510.pdf

Badan Pusat Statistik (2017a) Penduduk 15 Tahun Ke Atas Menurut Status Pekerjaan Utama 1986-2017 https://www. bps.go.id/statictable/2009/04/16/971/penduduk-15-tahun-keatasmenurut-\%0Astatus-pekerjaan-utama-1986---2017.html

Badan Pusat Statistik (2017b) Penduduk 15 Tahun Ke Atas yang Bekerja menurut Lapangan Pekerjaan Utama 1986-2017 https://www.bps.go.id/statictable/2009/04/16/970/penduduk15-tahun-ke-atas-yang-bekerja-menurut-lapangan-pekerjaanutama-1986---2017.html

Badan Pusat Statistik (2017c) Penduduk Berumur 15 tahun ke atas menurut jenis kegiatan tahun 1986-2017 https://www.bps. go.id/statictable/2009/04/16/969/penduduk-berumur-15-tahun-ke-atas-menurut-jenis-kegiatan-tahun-1986---2017.html

Badan Pusat Statistik (2017d) Tingkat Pengangguran Terbuka (TPT) Menurut Provinsi, 1986-2017 https://www.bps.go.id/ statictable/2014/09/15/981/tingkat-pengangguran-terbukatpt-menurut-provinsi-1986---2017.html

Bank Indonesia (2004) Laporan Perekonomian Indonesia Tahun 1998/1999. Jakarta. https://www.bi.go.id/id/publikasi/laporantahunan/perekonomian/Pages/LapTah 1998 1999.aspx

Bank Indonesia (2017) Tujuan Kebijakan Moneter Bank Indonesia http://www.bi.go.id/id/moneter/tujuan-kebijakan/ Contents/Default.aspx

Benati L (2015) The long-run Phillips curve: A structural VAR investigation. Journal of Monetary Economics 76: 15-28. https://doi.org/10.1016/j.jmoneco.2015.06.007

Bhattarai K (2016) Unemployment-inflation trade-offs in OECD countries. Economic modelling 58 (2016): 93-103. https://doi. org/10.1016/j.econmod.2016.05.007

Blanchard O (2016) The Phillips curve: Back to the '60s? American Economic Review 106 (5):31-34. https://doi.org/10.1257/ aer.p20161003

Brooks C (2008) Introductory econometrics for finance (2nd ed) Cambridge University Press. https://doi.org/10.1017/ CBO9780511841644

Caporale GM, Škare M (2011) Short- and long-run linkages between employment growth, inflation and output growth : evidence from a large panel. Economic and Finance Working Paper. London https://www.brunel.ac.uk/_data/assets/ pdf_file/0011/127487/1117.pdf

Cioran Z (2014) Monetary policy, inflation and the causal relation between the inflation rate and some of the macroeconomic variables. Procedia Economics and Finance 16 (May): $391-$ 401. https://doi.org/10.1016/S2212-5671(14)00818-1

Djambaska E, Lozanoska A (2015) Foreign direct investment and unemployment evidence from the republic of Macedonia. International Journal of Economics, Commerce and Management United Kingdom, III(12): 73-85.

Edelman M (2013) What is a peasant? What are peasantries? A Briefing paper on issues of definition. Intergovernmental Working Group on a United Nations Declaration on the Rights of Peasants and Other People Working in Rural Areas, Geneva, 15-19 July 2013. Geneva http://www.ohchr.org/Documents/ HRBodies/HRCouncil/WGPleasants/MarcEdelman.pdf
Ehrenberg RG, Smith RS (2012) Modern Labor Economics: Theory and Public Policy (Donna Battista, Ed) (11th ed) Boston: Pearson Education, Inc. http://fac.ksu.edu.sa/sites/ default/files/Modern_labor_economics_theory_and_public_policy_0.pdf

Furuoka F (2007) Does the "Phillips curve" really exist? New empirical evidence from Malaysia. Economics Bulletin 5 (16): 1-14. http://economicsbulletin.vanderbilt.edu/2007/volume5/ EB-07E20006A.pdf

Furuoka F (2008) Unemployment and Inflation in the Philippines: new evidence from Vector Error Correction Model. Philippone Journal of Development XXXV (1): 93-106. https://dirp4. pids.gov.ph/ris/pjd/pidspjd08-1unemployment.pdf

Hubacek K, Guan D, Barua A (2007) Changing lifestyles and consumption patterns in developing countries: A scenario analysis for China and India. Futures 39 (9): 1084-1096. https://core.ac.uk/download/pdf/51098.pdf

Israel K (2015) Reconsidering the long-run relationship between inflation and unemployment http://www2.gcc.edu/dept/econ/ assc/Papers 2015/ASSC 2015 - Israel, Karl-Friedrich.pdf

Ivanov V, Kilian L (2005) A practitioner's guide to lag order selection for VAR impulse response analysis. Studies in Nonlinear Dynamics \& Econometrics 9 (1): 1-36.

Katria S, Bhutto NA, Butt F, Domki AA, Khawaja HA, Khalid J (2011) Tradeoff between inflation and unemployment. In: Proceedings of 2nd International Conference on Business Management, 1-18 https://www.umt.edu.pk/icobm2012/ pdf/2C-90P.pdf

Kebschull D (1987) The role of the agricultural sector in the South by. Intereconomics, 125-126. https://doi.org/10.1007/ BF02932233

Keynes JM (1936) The general theory of employment, interest, and money. MacMillan and Cambridge University Press.

Kogid M, Asid R, Mulok D, Lily J, Loganathan N (2011) Inflation-unemployment trade-off relationship in Malaysia. Asian Journal of Business and Management Sciences 1 (1): 100-108 http://medcontent.metapress.com/index/A65RM03P4874243N.pdf\%5Cnhttp://www.ajbms.org/articlepdf/ ajbms_2011_1124.pdf

Lütkepohl H (2006) New introduction to multiple time series analysis. New York: Springer-Verlag.

Mahmood Y, Bokhari R, Aslam M (2013) Trade-off between Inflation, Interest and unemployment rate of Pakistan: A cointegration analysis. Pakistan Journal of Commerce and Social Sciences 7 (3): 482-492 http://www.jespk.net/publications/140.pdf

Mankiw NG, Euston Q, Wilson P (2013) Principles of economics: an Asian edition (2nd ed) Singapore: Cengage Learning Asia.

Okafor IG, Chijindu EH, Ugochukwu US (2016) Responsiveness of unemployment to inflation: empirical evidence from $\mathrm{Ni}$ geria. International Journal of Scientific Research in Science and Technology 2 (4): 173-179 https://www.researchgate. net/publication/311349523_Responsiveness_of_Unemployment_to_Inflation_Empirical_Evidence_from_Nigeria

Pallis D (2006) The trade-off between inflation and unemployment in the New European Union Member-States. International Research Journal of Finance and Economics (1): 80-88.

Phllips AW (1958) The relation between unemployment and the rate of change of money wage rates in the United Kingdom. Economica 25 (100): 283-299. 
Rosadi D (2012) Ekonometrika dan Analisis Runtun Waktu Terapan Dengan Eviews. Yogyakarta: ANDI.

Sa'idu BM, Muhammad AA (2015) Do Unemployment and inflation substantially affect economic growth? Journal of Economics and Development Studies 3 (2): 132-139 https:// doi.org/10.15640/jeds.v3n2a13

Sasongko G, Huruta AD (2018) Monetary policy and the causality between inflation and money supply in Indonesia. Business: Theory and Practice 19: 80-87. https://doi.org/10.3846/ btp.2018.09

Ştefan C, Bratu A (2016) The inflation-unemployment tradeoff in a macroeconometric model. British Journal of Economics, Finance and Management Sciences 12 (1): 22-31 http://www. ajournal.co.uk/EFpdfs/EFvolume12(1)/EFVol.12 (1) Article 3.pdf

Thayaparan A (2014) Impact of inflation on economic growth in Sri Lanka: a study of time series analysis. Global Journal of Management and Business Research: B Economics and Commerce 13 (5): 45-54. https://doi.org/10.11648/j. jwer.20160501.11

Touny MA (2013) Investigate the long-run trade-off between inflation and unemployment in Egypt. International
Journal of Economics and Finance 5 (7): 115-125. https:// doi.org/10.5539/ijef.v5n7p115

Ul-Haq I, Khan S, Khan A, Ahmed E (2012) Phillips curve or locus critique: time series evidence from Pakistan. Journal of Economics and Behavioral Studies 4 (4): 190-193 https://www. researchgate.net/publication/301551781_Revisiting_the_Phillips_Curve_and_the_Lucas_Critique

Umaru A, Zubairu AA (2012) An empirical analysis of the relationship between unemployment and inflation in Nigeria from 1977-2009. Economics and Finance Review 1 (12): 42-61. https://doi.org/10.1111/1467-8268.00061

Yelwa M, David OOK, Omoniyi AE (2015) Analysis of the relationship between inflation, unemployment and economic growth in Nigeria: 1987-2012. Applied Economics and Finance 2 (3): 102-109. https://doi.org/10.11114/aef.v2i3.943

Zaman K, Khan MM, Ahmad M, Ikram W (2011) Inflation, unemployment and the NAIRU in Pakistan (1975-2009). International Journal of Economics and Finance 3 (1): 245254. https://doi.org/10.1016/S2212-5671(12)00015-9 